\title{
A KONTROLLING FUNKCIÓ SZÉLESKÖRÜ ELTERJEDÉSÉNEK ÉS FEJLŐDÉSÉNEK SZÜKSÉGESSÉGE A KÖZSZFÉRÁBAN
}

\author{
Tóth-Kmoskó Éva \\ Kontrolling vezető Villeroy\&Boch Magyarország Kft.
}

\section{SUMMARY}

The goal of this article is to show my readers how important is to improve the public controlling function in order to achieve a conscious application of the modern economic methods in the public management area. The issue is that the financial resources of the state budget are limited; in this way we are able to compare the two existing sectors of this field identified as public and competitive sector. The comparison will demonstrate that there is an abundant need for the public sector to be more efficient and result oriented at all levels of the public finances. Basically, there are no or very limited use of holistic controlling activities in the public sector unlike in its competitive partner. What conclusion can be drawn from it? The answer is simple, ,adaptation". The public sector needs to adopt more of the controlling function, methods and systems from the competitive sector.

The results yield qualitative changes in the controlling field which include massive challenges and responibility for the next generation of the public controllers.

Kulcsszavak: kontrolling, közszféra, államháztartás, egészségügy

\section{BEVEZETÉS}

$\mathrm{Az}$ ezredfordulót követően regionális viszonylatban egy magas újraelosztási arány jellemzi Magyarországot. Az államháztartási bevételek meghaladták a környező országok átlagát, ez a magasabb adókulcsoknak volt köszönhető. A költségvetési kiadások terén az államadósság finanszírozásával együtt járó kamatterhek, valamint a szociális juttatások nyugdíjkiadások, családtámogatás - nagyobb aránya jellemző.

Sajnos hazánkban a produktív területek, mint az oktatás, az egészségügy, valamint az állami működési területek súlya mérséklődött, azaz a hosszú távú, fejlődést megalapozó ágazatok finanszírozási aránya csökkent.

A fenntartható fejlődés elve azonban megköveteli az államoktól a produktív területek elötérbe helyezését az ún. improduktív területekkel (nyugdij, szociális kiadások) szemben, csak így teremthetők meg egy sikeres központi gazdálkodás alapjai.

A stratégiai gondolkodás és az operatív irányítás egyik fontos segédeszköze a kontrolling, mely a versenyszférában már óriási területeket meghódított, míg a közszférában való megjelenése későbbre datálódik, és még igen nagy fejlődési potenciál rejlik benne. (Babucsik 2006., Kármán 2008.)

\section{KONTROLLING A KÖZSZFÉRÁBAN}

\subsection{A KONTROLLING SZEMLÉLETMÓD IRÁNTI IGÉNY A KÖZSZFÉRÁBAN}

A költségvetési szervek gazdálkodásának középpontjában az általuk nyújtott közszolgáltatás finanszírozása áll. A pénzforgalmi szemlélet - mely áthatja a közszféra gazdálkodását - csupán a bevételek és kiadások azonos szintre történő alakítását szolgálja. A szolgáltatások nyújtása kapcsán felmerülő pénzügyi kiadásokat bevételekkel kell lefedni.

Amennyiben párhuzamot kívánunk vonni a versenyszférában müködö, alapvetően profitorientált vállalkozásokkal, akkor ez a likviditás időszaki fenntartásának elvét kielégítő szemléletmód, csupán a cash-flow-ra koncentráló filozófia. (1. ábra)

Vajon elegendő-e ez a megközelítés, gondolkodásmód és módszertan akkor, amikor a szükséges forrásokat allokáljuk a közszféra szereplői számára? 
Válaszom egyértelmủen az, hogy a fenti szemléletmódot az európai - és ezen belül a magyarországi - gazdasági helyzet túlhaladta és óriási szükség van jelenleg a közszféra eredmény- és hatékonyság-orientált gazdálkodására az államháztartás minden szintjén.

1. ábra: A pénzforgalmi szemléletũ költségvetés és az üzemgazdasági eredmény összefüggése

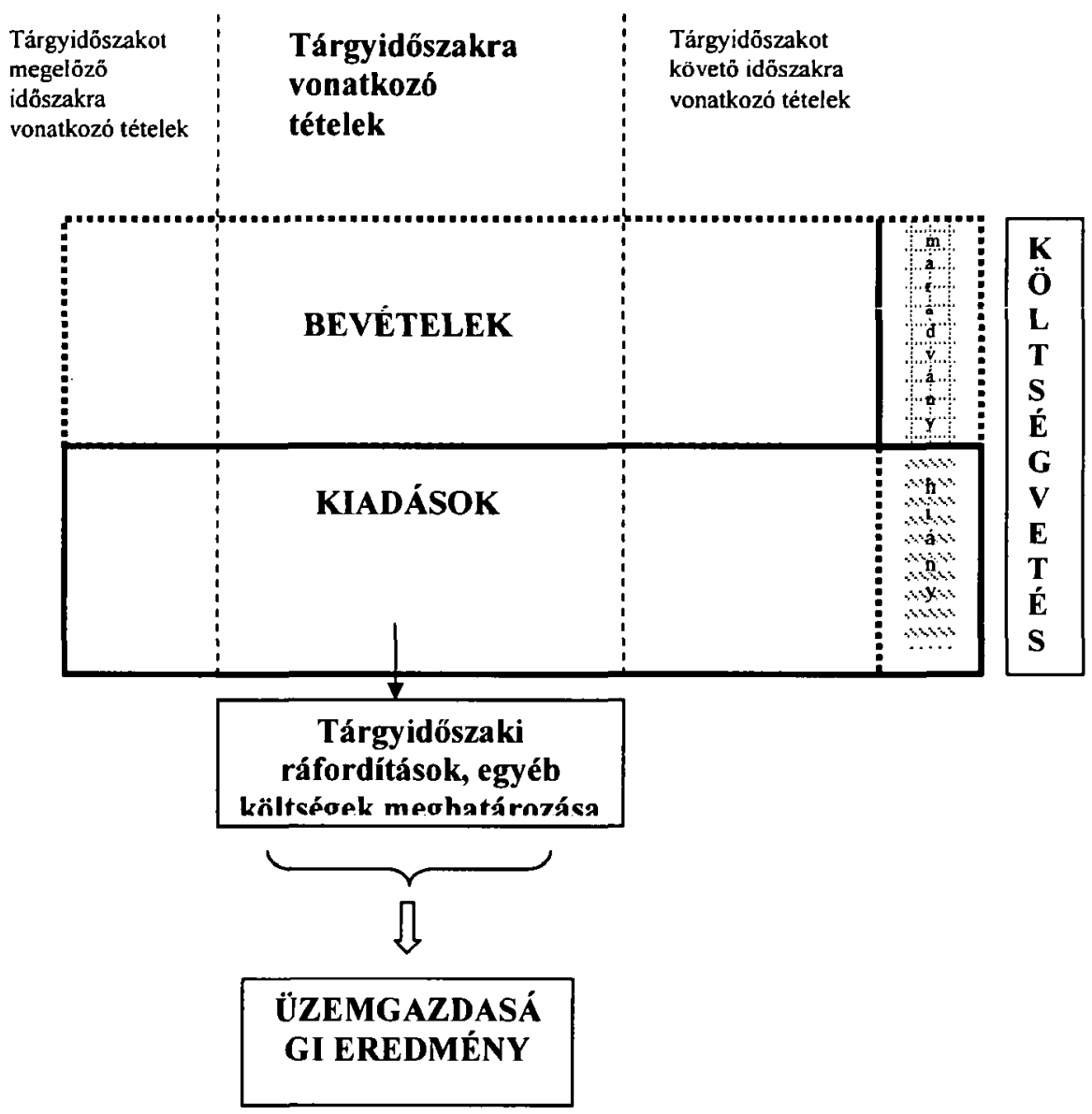

Forrás: A szerző saját szerkesztése

A költségvetési szférában az egészségügy területén figyelhettük meg a kontrollerek úttörő munkáját, de a honvédség és az önkormányzati intézmények is elmozdultak a kontrolling funkció alkalmazása felé. A következő fejezetben az egészségügyi intézmények kontrolling tevékenységébe kívánok bepillantást engedni.(Csermák 2000.) 


\subsection{A KONTROLLING ALKALMAZÁSA AZ EGÉSZSÉGÜGYBEN}

$\mathrm{Az}$ egészségügyi intézmények kontrolling tevékenysége kibontakozóban van az utóbbi években. Nyilvánvaló, hogy a válsággal és a folyamatos költségmegszorításokkal sújtott területen elötérbe kerül az egyes tevékenységek, osztályok, projektek profitszemléletü vizsgálata. Napjainkban egyre több kórház alkalmaz kontroller munkatársat az információs igények kielégítése érdekében.

A kontrolling rendszerek fő mozgatórugói a jól képzett és rátermett kontrollerek, akiknél sajnos napjainkban nem egyedi példa az elvándorlás a magasabb anyagi elismerést, valamint a jobb eszközellátottságot biztosító versenyszféra felé.

A kontrolling funkció sikere nagymértékben függ az intézmények menedzsmentjétöl, azaz, hogy maga a vezető milyen mélységü, milyen terjedelmü, milyen minőségü információellátottságot követel meg. Az egészségügyi intézmények vezetőivel szemben egyre inkább megjelenik a szakmai ismeretek szükségességén túl a közgazdasági gondolkodás követelménye, így mindinkább teret nyernek ezekben a pozíciókban az orvos-közgazdász végzettségü, vagy alap közgazdász végzettséggel rendelkező diplomások is.

Természetesen ennek a törekvésnek egy olyan szervezeti kultúrával is párosulnia kell, ahol az adatszolgáltatás az intézmény minden szintjén a tevékenységi kör kötelező eleme. Célszerü a kontrolling-szervezetet a menedzsmenthez közvetlenül hozzárendelni, függetlenül a számviteli és pénzügyi területektől.

$\mathrm{Az}$ egészségügyi kontrolling kiemelt kérdése a mögötte álló információ-technológia színvonala is. A szűkösen rendelkezésre álló finanszírozási források miatt az ország intézményei eltéró képet mutatnak.

Egyes intézményeknél saját fejlesztésü, föként Excel-alapú rendszerek müködnek, és az adatgyüjtés rendkívül időigényes. Szerencsés esetben biztosítva vannak az adatátemelések a könyvelési, a HR-, a készletgazdálkodási, valamint az eszköznyilvántartó rendszerekből. A legjobb megoldást az online-típusú integrált informatikai rendszerek jelentik, ahol az adatátemelések helyett a kontrolling alrendszerébe automatikus adatáramlás valósul meg. Ezzel biztositható a gyors, hatékony és az adatredundanciától mentes információszolgáltatás.

Magasabb színvonalú, komolyabb fejlesztői háttérrel rendelkező cégek is kínáljảk termékeiket, itt piacvezetői pozíciót ért el a budapesti székhelyü BSOFT Kft, amely jelenleg 65 egészségügyi intézményben van jelen és piaci részesedése $61 \%$-ot tesz ki.

A kontrolling információs rendszerek a következő szinten jelenhetnek meg az intézmény életében:

1. szint: a vezetői számvitel szintjén biztosítják a pénzforgalmi adatok üzemgazdasági szinttü adatokká, információkká való transzformálását. A ténykövetés a számviteli zárás (a tárgyhót követő hónap 10.napja) után valósul meg. Éves zárási munkálatok alatt ez az időpont a szük kapacitások miatt még inkább kitolódik. Ez a szint nem képes a pénzügyi adatokon kívüli mutatószámokkal, statisztikai adatokkal kooperálni.

2. szint: az üzemgazdasági adatok költséghelyeken és költségviselökön keresztül kerülnek elszámolásra, a tényadatok az intézmény struktúrájához, müködési területeihez illeszkedik. Neutrális mutatók is bekerülnek a rendszerbe. A tervezés és a visszamérés ezeken a szinteken - jellemzően osztályszinten - megvalósítható. Ekkor lehetővé válik a terv-tény szintủ elemzés és az osztály szintủ fedezetszámítás.

3. szint: nem csupán a mủködési területek, hanem a betegségcsoportok is górcsö alá kerülnek, a szolgáltatások ezen szintjén is kialakitásra kerülnek a fedezetszámítási rendszerek.

4. szint: az osztályok maguk müködtetik a tervezést és a monitorozást. 
A különbözö szintek meghatározzák azt az adatmélységet, mellyel a kontroller sáfárkodni tud. Emellett kiemelt fontossággal bír az idöhorizont, azaz, hogy a rendszerböl kinyert információk elérhetőek:

- a számviteli zárást követően,

- a vizsgált hónapot követö pár napban, vagy

- a tárgyhónapon belül, heti, vagy napi szinten.

$\mathrm{Az}$ ideálisnak nevezhető adatszolgáltatás jellemzően online integrált informatikai rendszerek segítségével valósítható meg, ahol a pénzügy, a számvitel, a humán erőforrásgazdálkodás, az eszköz- és készletgazdálkodás, a betegforgalom adatai az érintett alrendszerben történö rögzítéskor rendelkezésre állnak. Az információszükséglet gyakorisága téma-specifikus, hiszen a pénzkészleti adatokra, a likviditási mutatókra, a készletadatokra szükség lehet naponta, de a költség- vagy létszámadatokat elegendö havonta, míg a tárgyi eszközök alakulását negyedévente áttekinteni.

$\mathrm{Az}$ egészségügyi intézmények napjainkban saját forrásból jellemzöen nem tudnak megvalósítani egy komoly kontrolling-rendszer bevezetést, de az EU-s források kitörési pontot jelenthetnek számukra. (Zöldi 2006.2011. Koppány 2007.)

\subsection{A KÖZSZFÉRA KONTROLLING-RENDSZERÉNEK SIKERÉT AKADÁLYOZÓ TÉNYEZŐK}

A vezetôi döntéshozatalt rendkívüli módon támogatni tudja egy megfelelően kialakított és müködtetett kontrolling rendszer, melynek keretében a pénzforgalmi szemléletủ bevétel és kiadás-meghatározáson túl megtervezésre kerülnek az adott intézmény bevételei, müködési és egyéb ráfordításai elsősorban üzemgazdasági megközelítésben.

A közszféra kontrolling-rendszerének sikerét akadályozó tényezök:

- forráshiány az informatikai háttér kialakításánál;

- a közszféra ösztönzési rendszerének hiányosságai;

- hiányzik az intézményi szinteket átfogó, az egész gazdálkodási egységet jellemző kontrolling szemlélet

- a kontrolling rendszer kiépítése nem elegendö, a müködtetése intézményi szintü adminisztrációs fegyelmet és együttmüködést igényel;

- az ügyviteli folyamatok átszervezése nem mindig jár együtt a kontrolling információtechnológiai fejlesztésével;

- a kontrolling tevékenység gyakran a vezetői számviteli és a statisztikai adatszolgáltatásra korlátozódik, ezáltal nem jut elég erőforrás a belső adatszolgáltatásra, a vezetöi információs igény kiszolgálására, valamint a döntéstámogató, vagy döntés-elökészítö munkára;

- a kontrolling és a „controll” fogalmi keveredése miatt számos területen csak az adatok utánkövetése, a folyamatok pénzügyi ellenőrzése valósul meg, elhagyva, vagy háttérbe szorítva a tervezö, elörejelzö tevékenységet;

- hiányos a közszférában dolgozó kontrollerek speciális szakmai képzése, hiányzik a hasonló profilú intézmények szakmai kooperációja, a szakmai ismeretek szigetszerüen helyezkednek el, de nem aknázzák ki a szinergia-lehetőségeket. (Körmendi 1998.) 


\subsection{A MULTINACIONÁLIS CÉGEKRE JELLEMZŐ EGYSÉGESÍTÉS ADAPTÁLÁSI LEHETŐSÉGE A KONTROLLING RENDSZERẺBEN}

Véleményem szerint a közszférában - és azon belül a hasonló profillal rendelkezö intézményeknél - fellelhető eltérỏ színvonalủ kontrolling tevékenység akadályozza a források hatékony elosztását. Gondolatmenetemet a multinacionális cégek fejlődési irányvonalára építem, ezzel kivánok párhuzamot vonni az államháztartási alrendszerekben is alkalmazható irányvonalakkal.

A globális piacokon megjelenő, a világ számos pontján jelen lévő, termelő és szolgáltató cẻgek az információs rendszerük központosítására törekednek. Minden leányvállalat ugyanazon logikával felépített, harmonizált kontrolling rendszert igyekszik müködtetni. Miért nem alkalmazható ugyanez a logika a közszférában, hiszen számos hasonló profilú intézmény található hazánk városaiban, megyéiben, régióiban.

A nemzetközi cégek leányvállalatainál az adatok tartalmukban megegyeznek, függetlenül attól, hogy mely kontinensen, éppen milyen anyanyelvű kontroller továbbítja azt. Ez sokszor azonos törzsadatokat, kódolási rendszereket is feltételez.

A vállalatoknál a kontrolling struktúrák hasonlóak, a feladatok és a hatáskörök megegyeznek, függetlenül a földrajzi elhelyezkedéstöl. Miért nem alkalmazunk hasonló megoldásokat az iskolákban, óvodákban, kórházakban, önkormányzatoknál?

A cég egységes kontrolling irányelvei és módszerei megteremtik a cégcsoport kontrollerei között a "közös nyelvet". A hasonló profilú államháztartási intézmények szintén megteremthetik az egységes elveken és módszereken nyugvó kontrollingot.

A kontrolling rendszerek fejlesztéséhez a leányvállatoknál müködő szakemberek is hozzájárulnak, rendszeres szakmai konferenciák, vagy normál interperszonális kapcsolatrendszerük keretében eszmecserét folytathatnak, javaslatokkal segíthetik egymás munkáját. Mennyire hasznos lenne, ha a közszféra kontrollerei is áthidalnák az intézmények közötti fizikai távolságot, és szoros együttmüködést építenének ki egymással.

$\mathrm{Az}$ egységes beszámolórendszernek köszönhetöen a cégcsoport eredményei azonnal láthatóak, az ehhez történő leányvállalati hozzájárulás egyszerủen kivehető.

$\mathrm{Az}$ operatív beavatkozási pontok nyilvánvalóvá válnak és a stratégia célok meghatározásához is kellö és megbízható minöségü információs bázis áll rendelkezésre. Egy ehhez hasonló államháztartási információs platform megkönnyítené az adatok egységes kezelését, a gyors információáramlást és a hatékony döntéshozatalt. A leányvállalatok nem csupán a piaci versenytársakkal, hanem a többi leányvállalattal is összemérik teljesítményüket. A közszféra szereplői is, pl. az egészségügyi intézmények, vagy oktatási intézmények is összemérhetnék gazdálkodásuk eredményeit.

A stratégiai projektekért, a beruházási pénzekért és a jövedelmezőségi tervekből visszavezetett költségkeretekért „megvívnak” az egyes leányvállalatok, mely végeredményben a vállalatcsoport összeredményét, hatékonyságát és jövedelmezőségét jelentős mértékben meghatározza. Egy ehhez hasonló forrásleosztás az államháztartás jövedelmezőségi mutatóit, egyenlegét jelentősen javíthatná.

A közintézmények és azok fenntartói bizonyára számos kontrolling-elemet adaptáltak rendszerükbe, de az egységesítés és a korszerü kontrolling módszerek hiảnyoznak.

A közszférában jelenleg uralkodó szemléletet, események utókövetését, a lassú reakcióidőket, az átfogó stratégiaalkotás hiányát fel kell váltania egy megújult kontollingrendszernek. 


\section{3. ÖSSZEFOGLALÁS}

A közszféra teljes körü reformja véleményem szerint a rendszerváltás óta várat magára. A nagyarányú újraelosztás során - a hosszú távú fenntarthatóság érdekében - fontos szerepe van a produktív területek preferálásának.

$\mathrm{Az}$ állam sikerének egyik alapfeltétele, hogy a stratégiai és operatív célok felállitásához, vezetöi döntéshozatalhoz a közgazdasági szempontból tiszta, jól strukturált, követhetö és megfelelöen összehasonlitható információk, adatok rendelkezésre álljanak a megfelelö időpontban. A menedzsmentnek időben kell reagálnia a beavatkozást igénylö pontoknál, és országunk „hajóját" a kontrolling proaktív müködése révén a megfelelö irányba kell kormányoznia.

Megállapítható, hogy a jelenlegi rendszerben a kontrolling funkciót tekintve egy alulról építkezö fejlödési folyamatnak lehetünk tanúi, de ez a szigetszerüen, izoláltan fellelhető megoldás nem versenyezhet egy egységesített, a szinergia-lehetőségeket széles körben kiaknázó megoldással, mely a multinacionális vállalatoknál napjainkban már oly természetes. Nem léphetünk túl a közszféra kontrolling-rendszerének elmaradottságán, a közjó érdekében minden fórumon támogatnunk kell a versenyképes kontrolling-ismeretek megszerzését és adaptálását, valamint a kontrollerek megfelelö anyagi és szakmai támogatását.

\section{FELHASZNÁLT IRODALOM}

Babucsik Judit (2006): Mire költik a beszedett adókat? http://akadalymentes.apeh.hu/data/cms 1608/int0609cikk.pdf 2012.04.15.

Csermák Judit - Dér Géza - Nagy Istvánné - Pintérné Csermák Jolán (2000): Költségvetési szervek gazdálkodása, AULA Kiadó Kft. Budapest (52-66.old.)

Kármán András: A magyar költségvetés kiadási szerkezete nemzetközi összehasonlításban (2008):

Hitelintézeti Szemle, 2008. VII.évfolyam 6.szám (665-677.old)

Dr. Körmendi Lajos - Dr. Tóth Antal (1998): Controlling a hazai szervezetek gazdálkodási gyakorlatában, WEKA Szakkiadó Kft. Budapest (234-244.old.)

Zöldi Péter (2006): A kontrolling és a vezetöi információk jelentösége

Kórház 2006.12. szám 64-65.old.

Zöldi Péter (2011): Mérhetöség és kontroll a TIOP 2.2.4-ben

Kórház 2011.10. szám 46.old.

Koppány Tamás (2007): Nemcsak irányítani, hanem vezetni

Kórház 2007.10. szám 62-63.old. 